\title{
EVALUATION OF CORPORATE ENVIRONMENTAL RESPONSIBILITY IN BULGARIA AND GUIDELINES FOR ITS DEVELOPMENT
}

\author{
A. Miteva*, H. Petrov \\ Department of Economy of Natural Resources, University of National and World Economy, Sofia, \\ Bulgaria
}

\begin{abstract}
Corporate environmental responsibility has a positive impact on the efficiency and competitiveness of companies. The purpose of the report is to present the assessment of the implementation of corporate environmental responsibility in Evromaster Ltd and on this basis to propose guidelines and recommendations for its improvement.
\end{abstract}

Key words: corporate environmental responsibility, corporate environmental strategy

\section{INTRODUCTION}

The increasing resource scarcity and the deteriorated environment on the one hand and the ever-growing need of the people and the competitive environment among manufacturers make the environmental responsibility of firms a strategic issue of paramount importance for the future development and functioning of the economic system and living standards of the population. This problem is also valid for Bulgaria, as our country is not rich in resources, and many economic subjects have no traditions in rigorous application of norms, as well as the pursuit of environmental behavior.

The issue of corporate responsibility affects practically the entire society, and in Bulgaria it is significant as it lacks extensive experience and built own mechanisms to prevent nonresponsible practices and people as consumers either are not fully aware of their rights or not pay enough attention to this issue. In addition, corporate responsibility has different aspects, largely related to internal values and organization of companies. It should be noted that the environmental responsibility of companies is directly related to costs (in a positive or negative aspect) and their competitiveness. This issue is particularly

\footnotetext{
*Correspondence to: Albena Miteva, Sofia, UNWE, Economy of Natural Resources Department, tel: 0888 869620, e-mail: albenakm@yahoo.com
}

relevant at EU level, since two fundamental strategies for managing and protecting the environment - the Lisbon Strategy (2000-2010) and the Europe 2020 Strategy (to 2020) are applied during the last two decades. It should be noted that Bulgaria follows the priorities of these strategies after 2007 and applies their regulations - for labeling, classification of dangerous products, treatment of waste and others.

The purpose of the report is to present the assessment of the implementation of corporate environmental responsibility in Evromaster Ltd and on this basis to propose guidelines and recommendations for its improvement.

\section{CHARACTERISTICS OF CORPORATE ENVIRONMENTAL RESPONSIBILITY}

The concept of sustainable development requires interdependence between economics, ecology and social policy; comprehensive solution of the problems of the global-local chain; engaging all stakeholders in solving the problems; lack of opposition between human activity and environmental protection.

What is important is that the social and environmental components are considered in unity, so we can not talk about corporate social responsibility without taking into account corporate environmental responsibility.

For many researchers $(1,3,5,6)$, corporate social and environmental responsibility are 
intrinsically united. Other authors (2, 4) associate corporate social responsibility with the idea that society has certain expectations for the business which have to meet all or part of them. Corporate Social Responsibility in these definitions is seen as a form of corporate strategic management that sets the standards for leadership at a higher level compared to legal constraints and presents it as a system for managing the relationship between the firm and its environment.

According to the United Nations Industrial Development Organization, corporate social responsibility is a management concept whereby companies integrate social and environmental components into their business, as well as in relationships with related parties and contact groups. Accordingly, CSR is seen as a way for companies to balance between economic, environmental and social goals while meeting the expectations of shareholders and related parties.

Corporate environmental responsibility in the narrow sense is limited to active or passive actions with which the companies seek to limit the harmful environmental impacts of their activities.

These definitions do not reflect the full range of business relationships. For example, environmental management and improvement activities can also have indirect social effects (improving the living environment) and not just positive eco-effects. On the other hand, certain social activities can have a negative impact on the environment - the provision of business cars stimulates travel and, therefore, air pollution.

It can be summed up that under corporate environmental responsibility we can understand the voluntarily undertaken by companies commitments that go beyond general legal and customary requirements and companies are responsible for the effect of their activities on society and the environment. Environmental responsibility must be initiated and driven by companies, and public institutions have a supportive role through a mix of voluntary measures and, where necessary, mandatory regulations. This gives grounds to conclude that the economic content of environmental responsibility is related to the pursuit of a set of targeted activities to achieve certain economic, social and environmental objectives.

\section{EVALUATION OF THE APPLICATION OF CORPORATE ENVIRONMENTAL RESPONSIBILITY BY EUROMASTER OOD}

The assessment is based on information gathered through a literature review, expert assessments of company representatives, general data from reputable sources on corporate responsibility using the classification of firm indicators applied by the National Statistical Institute as well as specific methods for collecting information about the state of corporate environmental responsibility - GRI G4, LBG, etc., as well as in-depth interviews with representatives of the company's employees and management. On this basis, trends and recommendations to improve efficiency in corporate responsibility are drawn.

The method GRI G4 has serious advantages in the systematization of information in connection with the general guidelines for corporate environmental responsibility and presenting of a strategy for improving environmental performance. At the same time it is difficult to apply in connection with the operational activity of the company regarding the implementation of the strategy for environmental responsibility.

The analysis according to method GRI G4 enables companies to systematically present their progress on sustainable development goals, to tell their "environmental history" to clients and stakeholders, to give their interpretation of trends in environmental responsibility and sustainable development. Company analysis shows the existing progress towards sustainable growth, while the figures also show its benefits in terms of revenue and profits. At the same time, the findings of the analysis illustrate how companies bind their responsible behavior to building a positive image among current and potential consumers. Last but not least, they incorporate global environmental goals into their environmental strategies so they can meet the new requirements and market conditions.

Euromaster does not have its own production but has its own brands and executes development activities. Because of these specifics, environmental analysis focuses on product lifecycle management activities and the environmental component in the development of new products and concepts. Following the methodology of GRI, the following main directions of Euromaster's 
sustainable development policy are defined technological leadership, customer relations and social responsibility.

In the case of technology leadership, the company strives to develop and offer its customers products that bring maximum benefit to the organization and stakeholders. To ensure technological leadership, the company aims to convert the needs and expectations of customers and other stakeholders into requirements for their products; enhancing competitiveness by strengthening and developing the strengths of the organization, technological and technical modernization; maintaining partnership and mutually beneficial cooperation with suppliers; improving work organization through planning; systematically conducting trainings to raise staff qualifications and motivation for high quality work and inner attitude for constant and measurable improvements in dayto-day work; maintaining the compliance of the Quality Management System with the requirements of the international standard ISO 9001: 2015 and the applicable regulatory requirements.

Based on the listed goals and objectives, it can be concluded that the company is attempting systematically to define its priorities in terms of responsibility. It is noticeable that no environmental objectives are mentioned and that there is no link with national and/or European guidelines on liability. In terms of this parameter, the company's responsibility is limited to specific business goals and values such as fair customer attitude, competitive advantage, and more. In our opinion, if Euromaster's policy of responsibility clearly integrates goals from a higher (national, supranational) level, the company would be more seriously accepted from in public auctions and international clients with whom it works.

The second strategic direction for development is the customer and the primary concern of the company is to respond to the highest degree of their expectations for the quality of the products and the quality of the service. That is why are used the following measures: building a positive relationship with all clients and partners; permanent feedback from the market through various forms of consumer satisfaction research; instant response to any query, offering products that best match client searches; high level of service, speed and accuracy of deliveries, positive attitude towards the customer; training employees to build skills for customer-oriented behavior and to enhance professional qualifications and competence.

We can summarize that direct business objectives and values are also included here, as in future inquiries and customer requirements, if the search for products in ecological characteristics appears, the company will invest efforts and resources in this direction. In terms of training, employee upgrading qualification is a company's priority, even though employee training plans should also include issues such as environmental and social responsibility.

The third direction is social responsibility, as the company realizes that dynamic business development means more "responsibility to the surrounding world". Company representatives say that responsibility is monitored and managed as other business indicators. They use their own assessment methodology and it is important for them to implement as many projects as possible, such as support for sports clubs and initiatives: children fencing tournament, rally Montana 2013, support of Kazanlak volleyball club, support for children from the sports club "Herea" in connection with their international participation, etc ;; construction of playgrounds - is realized a project for a playground in Toleva mahala; participation in national initiatives by providing oars and tools in the "Let's Clear Bulgaria for a Day" initiative.

Taking a full look at the company's responsibility for the environmental component and society in particular, is seen that Euromaster wants to work on these areas. The company does not have a comprehensive vision of environmental management but broadens its initiatives in this direction and seeks to build positions in this area as well.

Since social and environmental responsibility also has an economic component, it can be concluded that the company's economic performance allows it to implement its CSR policy. Euromaster has a $14.2 \%$ increase in sales revenue in 2016, with an increase in the absolute value of the company's profits. In terms of spending, there is an increase of $7.8 \%$ in personnel costs, which in terms of the values and perceptions of the liability of the company can be considered as a positive trend in this direction. 
The GRI G4 ecological accountability for the Bulgarian company Euromaster is modest in terms of scope, detail of information and systemic comparability than large international companies, but gives possibilities for recommendations on the basis of trends and good practices in large companies.

The next is the LBG method. It allows the assessment of specific projects and the measurement of the results of the actual application of the activities related to the set environmental objectives. Practically, without serious financial investments, the company manages to present itself to an important target group in the future and to position itself as a responsible for society. The method is applied to the participation of Euromaster in bTV's initiative "Let's Clear Bulgaria for a Day" in 2013 and is illustrated in Table 1:

Table 1. Application of the LBG Method to the Euromaster's environmental activity

\begin{tabular}{|c|c|c|}
\hline Resources & Results & Effect \\
\hline $\begin{array}{l}\text { How: Provide } 12,000 \\
\text { gloves from the company's } \\
\text { assortment }\end{array}$ & \multirow{2}{*}{$\begin{array}{l}\text { Society: Improving living } \\
\text { conditions for residents of the } 3 \\
\text { largest cities in Bulgaria (with a } \\
\text { total population of over } 2 \\
\text { million inhabitants) }\end{array}$} & \multirow{3}{*}{$\begin{array}{l}\text { Beneficiaries: The direct } \\
\text { beneficiaries are the organizers } \\
\text { and participants in the } \\
\text { campaign, and the final benefits } \\
\text { are for the inhabitants of the } \\
\text { settlements }\end{array}$} \\
\hline $\begin{array}{l}\text { - Why: The company } \\
\text { demonstrates its values for }\end{array}$ & & \\
\hline $\begin{array}{l}\text { more responsibility to the } \\
\text { surrounding world }\end{array}$ & \multirow{2}{*}{$\begin{array}{l}\text { Synergy: The company } \\
\text { becomes part of a widely } \\
\text { advertised project of national } \\
\text { importance }\end{array}$} & \\
\hline $\begin{array}{l}\text { Location: Sofia, Varna, } \\
\text { Plovdiv }\end{array}$ & & \multirow{2}{*}{$\begin{array}{l}\text { Business Effects: Positive } \\
\text { Image Positioning, Media } \\
\text { Coverage }\end{array}$} \\
\hline $\begin{array}{l}\text { What: Better living } \\
\text { conditions and a } \\
\text { responsible attitude to the } \\
\text { environment }\end{array}$ & $\begin{array}{l}\text { Benefits for business: A } \\
\text { desirable image of the } \\
\text { company, recognizable among } \\
\text { target groups, media coverage }\end{array}$ & \\
\hline
\end{tabular}

Euromaster's involvement in this initiative demonstrates that social and environmental responsibility is not a reserved area for major international companies, and when properly planned, such participation can receive broad media coverage.

Regarding the United Nations Development Program's self-assessment tool, the application of the GRI methodology largely covers the areas on which it focuses. However, it contributes to the analysis by focusing on four main components related to the environmental performance of companies: human rights, working conditions, the environment, anti-corruption. What we can distinguish Euromaster that has a longstanding cooperation with the Association of Deafblinds in Bulgaria and the implementation of a company program for job creation and rehabilitation for physically disabled people. The application of this tool demonstrates practices that contribute to the sustainable operation and development of the business of the research sites and which can be implemented by other companies in Bulgaria. In order to obtain full objective information, in-depth interviews with employee representatives and management staff were conducted to assess the state of implementation of environmental and social responsibility in the company. The motivation for applying an environmental responsibility strategy has been studied and two main groups of motives are formed. On the one hand, these are the regulatory requirements for improving the environmental performance of companies that underpin the implementation of the environmental responsibility strategy. On the other hand, these are the trends in the development of the markets and the companies themselves, which can be guidance from the parent company, good practices from competitors, partners and other businesses. The analysis shows the growing importance of voluntary instruments, especially in businessto-business ones. When participating in large projects, both environmental product performance declarations, Environmental Management System Certificates and Quality Management Systems are increasingly required. This is how the legislative and legal framework sets the foundations for the company's environmental behavior, and with the help of voluntary instruments this behavior builds is upgraded.

On next place the respondents reveal the main challenges, and greatest difficulties are being encountered in implementing measures for 
improving environmental impact. The difficulties are related to clarifying the new procedures and requirements for environmental behavior, the short deadlines for implementation of relevant environmental practices as well as the additional costs and complicated (at least at early stages) procedures for dealing with counterparties. For managers, the problems come from both the markets and the achievement of growth goals. Still, senior management goals are primarily related to financial results for the year or quarter and are not directly related to the environmental performance of companies. In this situation, even short-term price increases as a result of improved environmental performance may negatively affect the financial targets for the period.

When examining the benefits of implementing the company's environmental responsibility strategy, we state compliance with the law and on this basis - security for employees and for the company. The above-mentioned requirements in $\mathrm{B} 2 \mathrm{~B}$ relationships give priority to companies that invest in improving their environmental performance above the minimum level required by law. Certificates and other company/product environmental documents are also available for projects and auctions where they are not mandatory, but the company shows that "there have something more" over what competitors offer.

When revealing the expected major trends in environmental responsibility, all respondents expect an increase in environmental requirements without exception. There is an increasing awareness of markets and customers, raises the sensitivity to the environmental component of business activity, and the wide communication opportunities have an increasingly important impact on the way companies perform their business.

The biggest problem in the future is uncertainty about the legal requirements in the environmental field. For large companies, the problem is that they believe that control institutions first check large firms and, despite the existence of a serious resources (legal aid, consultancy, etc.), they are not always aware of the concrete application of these requirements . They see a solution in improving the regulatory base and more real interaction between the institutions and the business. For representatives of smaller companies, the problem lies more in the way they have to apply environmental requirements and lack of resources for interpretation and eventual payment of sanctions and fines.

\section{CONCLUSION}

Corporate responsibility has a positive impact on the efficiency and competitiveness of companies. This conclusion allows us on the basis of the state, the experience and the main trends that determine the operating environment of the companies, to provide guidelines and recommendations to them in relation to the implementation and development of their corporate environmental responsibility for:

- Improving the company's internal (eco) efficiency

In this connection, we dare to make recommendations to both parties. Although many institutions are updating their sites and publishing news about environmental legislation, they should more actively interact with the business, more actively organize and conduct seminars and, if possible, take into account business feedback, as well as to invest more resources in organizing thematic trainings. Business recommendations also relate to more active work with institutions and active search for information. Some participants have made assumptions that "it is not the job for ministries to travel around companies" and modern information and communication tools make it more and more accessible to find recommendations and instructions for implementing environmental regulations.

Businesses should be more actively participate in branch associations (of course, within the limits of antitrust law). We believe that the exchange of views will help to better understand the changes and their more effective implementation, and also create opportunities for exchange of experiences and good practices. Proven good practice is also taking part in discussing legislative changes by this type of associations.

- Effective implementation of environmental policy instruments

Companies, on the one hand, make efforts to comply with environmental legislation, and on the other - gradually begin to see the meaning of the application of voluntary instruments. Nevertheless, companies are not looking for synergy either between the different types of instruments, thus the full potential of the environmental policy instruments being used is insufficient. 
Regarding regulatory instruments and expected changes (usually tougher) to environmental requirements, they can be used as an argument and in defense of investment plans for technology upgrading. Thus, the company will be able to set the right priorities in its investment program and to take into account the importance of new environmental requirements. Earlier introduction of new (and usually more efficient) technologies brings benefits in terms of both the company's environmental performance and profitability. On the other hand, if insufficient attention is paid to the necessary changes in relation to the new environmental requirements, it is possible to exceed the investment budget over a given period, thus resorting to external financial resources and worsening business efficiency.

With regard to certification tools, when a company has an ISO 14001 certificate for Environmental Management System and ISO 9001 for Quality Management and ISO 18001 for Health and Safety, more value is added to its products and reputation. In front of its trading partners, contractors and other stakeholders, the company can claim that it produces high quality products in an environmentally friendly way and under safe conditions for employees. This can be beneficial to the company when participating in major projects with environmental requirements or in public auctions where there are non-price criteria. In addition, this practice is a reliable argument for maintaining certain price levels on the part of the responsible companies.
MITEVA A., et al.

Last but not least, voluntary labeling systems have the potential to bring benefits in terms of providing market recognition for the companies. In many sectors outside the business, companies are looking for some recognition (quality award, market share leadership, etc.) to distinguish them from their competitors. For responsible companies, the possession of an environmental certificate is a sound basis for communicating with the market, given the growing awareness of consumers.

\section{REFERENCES}

1. Dietz, T., Stern, P.: New Tools for Environmental Protection: Education, Information and Voluntary Measures, National Academy Press, 2002

2. Jordan, A., Wurzel, R., Zito, A.: The Rise of 'New' Policy Instruments in Comparative Perspective: Has Governance Eclipsed Government?, University of Anglia, 2005

3. Kokubu, K., Nakano, M., Nakao, Y., Amano, A.: Corporate environmental and financial performances and the effects of information-based instruments of environmental policy in Japan, International Journal of Environment and Sustainable Development, 2007

4. Lankoski, L: Differential Economic Impacts of Corporate Responsibility Issues, Business and Society, Vol. 48, 2007

5. Newig, J., Fritsch, O.: Environmental governance: participatory, multi-level - and effective, 2009

6. Sterner, T.: Instruments of Environmental Policy, Elanders Novum, 2003 